\title{
Municipal wastewater can result in a dramatic decline in freshwater fishes: a lesson from a developing country
}

\author{
Shams M. Galib ${ }^{1,2,{ }^{*}, a}$, A.B.M. Mohsin ${ }^{1, a}$, Md. Taskin Parvez ${ }^{1}$, Martyn C. Lucas ${ }^{2}$, Nipa Chaki ${ }^{3}$, \\ Sadman S. Arnob ${ }^{4}$, Md. Istiaque Hossain ${ }^{1}$ and M. Nazrul Islam ${ }^{5}$ \\ ${ }^{1}$ Department of Fisheries, University of Rajshahi, Rajshahi 6205, Bangladesh \\ ${ }^{2}$ Department of Biosciences, University of Durham, Durham DH1 3LE, UK \\ ${ }^{3}$ Department of Geography and Planning, University of New England, NSW 2351, Australia \\ ${ }^{4}$ Department of Soil, Water and Environment, University of Dhaka, Dhaka 1000, Bangladesh \\ ${ }^{5}$ Department of Zoology, University of Rajshahi, Rajshahi 6205, Bangladesh
}

\begin{abstract}
Impacts of ineffective wastewater management on the biodiversity of receiving waters in developing countries are poorly documented. Using a before-after-control-impact methodology, we measured the effects of untreated wastewater release on the fish community in the Barnoi River, Bangladesh. In 2006, prior to untreated wastewater discharge, fish abundance, species richness and water quality were similar across sampling sites. In 2016, after 8 years of wastewater release to the downstream reach, fish abundance and species richness were reduced by $>47 \%$ and $>35 \%$ respectively at downstream sites compared to unaffected upstream sites and $>51 \%$ and $>41 \%$ lower respectively compared to the pre-wastewater discharge period. The wastewater impact was particularly severe during months of low discharge (October-December). Water transparency, dissolved oxygen and $\mathrm{pH}$ were lower $(P<0.001)$ at impacted downstream sites compared to upstream sites. Nineteen species $(41.3 \%$ of all species we recorded) are threatened in Bangladesh and the abundance of these species, except one, decreased significantly $(P<0.05)$ at the impacted sites. We recommend improved wastewater management by applying primary treatment facilities and incorporating reedbed filtration as a mean of biological treatment, into the canals carrying wastewaters. The success of such measures should be tested with fish species that were most responsive to wastewater, using the indicator species concept.
\end{abstract}

Keywords: Wastewater / water pollution / biodiversity loss / threatened fish / BACI

Résumé - Les eaux usées municipales peuvent entraîner une baisse spectaculaire du nombre de poissons: un exemple d'un pays en développement. Les impacts d'une gestion inefficace des eaux usées sur la biodiversité des eaux réceptrices dans les pays en développement sont mal documentés. En utilisant une méthodologie BACI, nous avons mesuré les effets des rejets d'eaux usées non traitées sur la communauté de poissons de la rivière Barnoi, au Bangladesh. En 2006, avant le rejet des eaux usées non traitées, l'abondance des poissons, la richesse en espèces et la qualité de l'eau étaient semblables dans tous les sites d'échantillonnage. En 2016, après 8 ans de rejet d'eaux usées dans le bras aval, l'abondance des poissons et la richesse en espèces ont été réduites de $>47 \%$ et $>35 \%$ respectivement sur les sites en aval par rapport aux sites en amont non affectés et $>51 \%$ et $>41 \%$ respectivement par rapport à la période de rejet avant le rejet des eaux usées. L'impact des eaux usées a été particulièrement grave pendant les mois de faible débit (octobre-décembre). La transparence de l'eau, l'oxygène dissous et le $\mathrm{pH}$ étaient inférieurs $(P<0,001)$ aux sites impactés en aval par rapport aux sites en amont. Dix-neuf espèces (41,3\% de toutes les espèces que nous avons recensées) sont menacées au Bangladesh et l'abondance de ces espèces, sauf une, a diminué de façon significative $(P<0,05)$ dans les sites touchés. Nous recommandons d'améliorer la gestion des eaux usées en appliquant des

\footnotetext{
*Corresponding author: shams.m.galib@durham.ac.uk

${ }^{a}$ Both authors (Shams M. Galib and A.B.M. Mohsin) should be treated as the first author.
} 
installations de traitement primaire et en incorporant la filtration sur lit de roseaux comme moyen de traitement biologique dans les canaux transportant les eaux usées. Le succès de ces mesures devrait être testé avec les espèces de poissons les plus sensibles aux eaux usées, en utilisant le concept d'espèces indicatrices.

Mots-clés : Eaux usées / pollution de l'eau / perte de biodiversité / poissons menacés / BACI

\section{Introduction}

Worldwide, freshwater habitats are being exposed to a complex mixture of stressors including water pollution and habitat degradation (Dudgeon et al., 2006; Dirzo et al., 2014), threatening the diversity of life (Moss, 2008; Vorosmarty et al., 2010). Rivers can be particularly vulnerable to receiving chemical stressors from anthropogenic origin, including organic matter and inorganic nutrients (Moss, 1998), and micropollutants such as pesticides or industrial products (Meybeck, 2004; Sabater et al., 2016). Part of the reason for this is that rivers are employed to dilute and transport treated wastes away from human populations. The impacts of pollution and other stressors on freshwater ecosystems can be detrimental because decreasing biodiversity reduces the ability of ecological communities to provide many fundamental ecosystem services (Keesing et al., 2010). However, the intensity of threats to freshwater biodiversity in tropical Asia is exceptional compared to other parts of the world because of a complex mixture of different factors (e.g. dense population, deforestation, and flow regulation; see Dudgeon, 2005 for details).

While the impacts and remediation of freshwater pollution, especially organic pollution, have a long and well-recorded history in the developed world (Hynes, 1963; Mason, 2001), wastewater is a serious and emerging problem in the majority of developing countries (e.g. Girija et al., 2007; Omosa et al., 2012; Haque, 2017). This is primarily because industrial, agricultural, municipal and sewage discharge cause deterioration of receiving water quality (Dudgeon, 1992; Vaseem and Banerjee, 2013; Paul, 2017) and make freshwater habitats unfavourable for natural communities of micro and macroorganisms living in the system (Karaouzas et al., 2018). The majority of research carried out on wastewater pollution in Asia focuses on changes in the receiving water's physicochemical quality and sediments (e.g. Kumar and Reddy, 2009; Dai et al., 2018; Rajeshkumar et al., 2018; Ramachandra et al., 2018); impacts on invertebrate communities (e.g. Morse et al., 2007 summarised the status of East Asian countries) or impacts on the physiology of individual fish species (e.g. Sanchez et al., 2011; Vaseem and Banerjee, 2013; Yazic1 and Sisman, 2014). Few studies have reported impacts of water pollution on fish communities in tropical Asia (except see Dudgeon, 1992, 2002; Mulk et al., 2016). However, these fish studies often lack long-term data that can explain responses of aquatic biota to stressors and that can quantify changes in the target community over time and space.

In Bangladesh, water pollution has resulted from unplanned urbanization and industrialization and is of high concern (Ali et al., 2016; Kibria et al., 2016; Haque, 2017). Primarily with a perspective of human health risks, several studies have been conducted with a view to assessing metal concentrations in waters (e.g. Ali et al., 2016; Kibria et al., 2016; Bhuyan and Bakar, 2017) and also in the bodies of aquatic animals living in polluted waters (e.g. Ahmed et al., 2015; Islam et al., 2015). Although it is believed that freshwater fishes in inland waters of Bangladesh have declined markedly because of pollution (e.g. Hussain, 2010), no studies have been carried out to date to address its actual impacts on fish communities. Although elevated levels of heavy metals are common in urban or industrial wastewaters, oxygendemanding organic waste is often the predominant polluting component and has the potential to cause dramatic changes in biodiversity in tropical freshwaters (Dudgeon, 2002). Therefore, we sought to determine the extent of degradation to natural biota due to long-term discharge of wastewaters from nearby municipal, agricultural and small-scale industrial sources, using the Barnoi River in northern Bangladesh as a case study.

In this study, we analysed changes in fish abundance, species richness and water quality parameters over time and space in relation to current wastewater management practice using a before-after-control-impact (BACI) approach. We hypothesized that wastewater disposal would have negative impacts on the fish abundance, species richness and water quality at the sampling sites receiving wastewaters compared to unaffected sites in the Barnoi River.

\section{Methods}

\subsection{Study area}

The Barnoi River (Fig. 1), whose upstream part is known as the Shiva River, originates from the Manda floodplain in the Tanore sub-district of Rajshahi district (Bashar et al., 2009), in north-west Bangladesh. The Barnoi channel can be up to $25 \mathrm{~m}$ wide and $3 \mathrm{~m}$ deep during the wet season (June-September). This river joins the Gumani River (at $24^{\circ} 33^{\prime} 27^{\prime \prime} \mathrm{N} 88^{\circ} 48^{\prime} 34^{\prime \prime} \mathrm{E}$ ) at Bagmara Upazila (sub-district) of Rajshahi district.

In 1994, the Rajshahi City Corporation (local municipality) passed a plan for the construction of two canals that would drain municipal wastewaters into the Barnoi River. The construction works finished in December 2008 and became operational immediately and since then the river has continuously been receiving wastewaters from Rajshahi City Corporation through two canals (each $5.1 \mathrm{~m}$ wide and $2.4 \mathrm{~m}$ high; Fig. 1). These wastewaters contain untreated kitchen wastes, water containing detergent from households, run-off from streets and often faeces and urine (this is not legal but many households illegally installed underground pipes between sewage tanks and drains; also when sewage tanks become full many residents empty their tanks by draining the faeces into nearby drains). Currently, there is no 


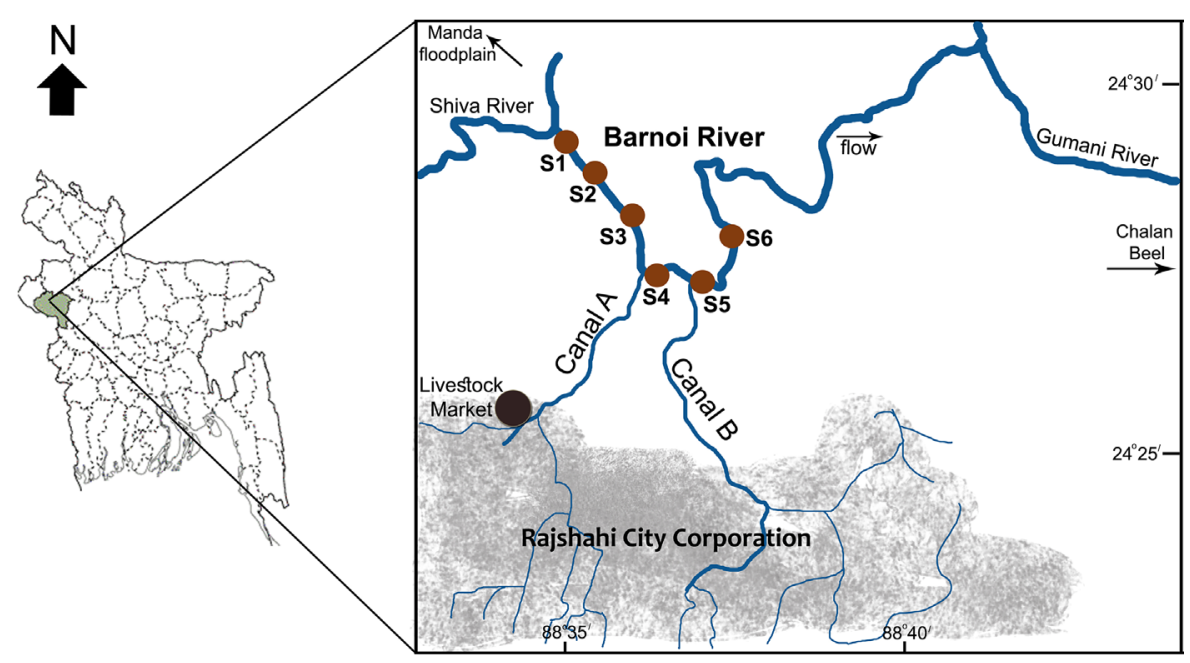

Fig. 1. Map of the Barnoi River showing sampling sites $\left(S_{1}-S_{6}\right)$ and the two major canals $(A$ and $B)$ that carry untreated wastewater to the river.

wastewater-treatment facility in the study area and thus untreated wastewaters are being drained directly into the river. Moreover, a large livestock wholesale market (locally know as City Hat) is situated by one of these canals (canal A; Fig. 1) and dead animals (primarily cattle, goats and buffalo) and organic waste products from slaughtered animals from this market are often thrown into the canal. Canal A also receives pharmaceutical and clinical waste (used medicine bottles, syringes, bandages, etc.; Fig. S1). These two canals join the Barnoi near Duari and Nowhata points (sampling points $\mathrm{S}_{4}$ and $\mathrm{S}_{5}$ in this study, Fig. 1) and there has been a concern for its impact on aquatic biodiversity and riverine habitat among local people since the wastewater canals opened. Reduced fish catch and bad odour from harvested fish have been reported by the local people in these areas. Local fishermen also reported complete loss of a fish breeding ground located between sampling site $S_{5}$ and $S_{6}$ due to untreated wastewater mixing with the river water (T. Pervez and S. Arnob, pers. obs.).

Although two sluices have been built to regulate the waters in the canals joining the Barnoi the untreated wastewater has continuously flowed into the river through broken and partially opened gates (Fig. S2). These sluices were once managed by the government officials but since 2015 no personnel have been appointed for this purpose and they were being operated (i.e. fully opened) by local people whenever needed depending on the accumulation of wastewater. Although there are no statistics of wastewater flowing into the Barnoi River, during the dry season when the river water becomes almost stagnant, the wastewater from these two canals constitutes the only water flow.

\subsection{Fish sampling and study approach}

Fish sampling at six sites $\left(\mathrm{S}_{1}-\mathrm{S}_{6}\right.$; Fig. 1$)$ in the Barnoi River was conducted on eight occasions between July and December in each of 2 years, 2006 (before the wastewater canals opened) and 2016 (8 years after the wastewater canals opened). Each sampling site was $\sim 3 \mathrm{~km}$ distant from neighbouring sites. From
January to June the water depth in the river became too shallow for the operation of fishing gears and thus it was not possible to carry out sampling. Sampling dates were not the same in both years (varied by \pm 3 days) but the number of samples in each month in both years were the same. All samples at all sites in 2006 represent pre-waste outflow conditions. In 2016, three sampling sites $\left(\mathrm{S}_{4}-\mathrm{S}_{6}\right)$ were affected by the wastewater carried through two channels as these sites were located downstream of the outlets (Fig. 1) and samplings carried out that year represent post-waste outflow samples. This setup enabled a balanced BACI analysis approach (Downes et al., 2002; Boys et al., 2012) to be used in this study. In this study, sampling years (2006 vs. 2016) represents "before-after (BA)", and location (upstream $\left[\mathrm{S}_{1}-\mathrm{S}_{3}\right] /$ downstream $\left[\mathrm{S}_{4}-\mathrm{S}_{6}\right]$ ) resembles "control-impact $(\mathrm{CI})$ " sites of a BACI design.

All sampling sites appeared similar in habitat with a sand and mud bottom (about 50:50 ratio), with a channel width of $\sim 30 \mathrm{~m}$ and gently shelving banks to a maximum depth of 4-6 $\mathrm{m}$ at the peak of the flood. In 2006, the water depth was quite similar between upstream and downstream sites over the sampling period. In 2016, although the water depth was similar (4-6 $\mathrm{m}$ ) between upstream and downstream sites during the wet period (July-September) it was slightly greater at downstream sites $(2.5 \pm 0.2 \mathrm{~m})$ during the dry season (October-December) compared to upstream sites $(2.2 \pm 0.2 \mathrm{~m})$. No water flow measurements were taken but it was noticed that there was almost no flow at the upstream sites over the drying months whereas slow-flowing water $\left(<0.05 \mathrm{~ms}^{-1}\right)$ was noticed at the downstream sites. It may be assumed that these differences in water depth and flow at downstream sites were due to wastewater addition to sites located downstream. Vegetation on both banks of the river was similar at all the sampling sites in both years. In 2006, the water surface near both banks at all the sampling sites were partially covered $(\sim 10 \%)$ by marginal aquatic macrophytes, i.e. Alternanthere, Ipomoea, and Marsilea spp. But marginal macrophyte vegetation reduced to below $5 \%$ at the downstream sites in 2016 with a blackish/greyish layer of silt on the macrophyte leaves, whereas the upstream part remained almost unchanged (8-10\% cover). 
At the sampling sites, on a given occasion, fishes were collected with three cast nets (mesh $10 \times 10 \mathrm{~mm} ; \pi \times 1.25^{2}$ $\left.\mathrm{m}=4.9 \mathrm{~m}^{2}\right)$, two lift nets (mesh $\left.10 \times 10 \mathrm{~mm}, 5 \times 4.5 \mathrm{~m}\right)$ and three rectangular fishing traps locally known as "Kholsun" (made of split bamboo sticks; mesh $20 \times 20 \mathrm{~mm}, 0.8 \times 0.8$ $\times 0.1 \mathrm{~m}$ ). Fishing traps were set in the evening before the day of sampling and left overnight (approximately $15 \mathrm{~h}$ ) in the water. The lift nets were hauled five times at each sampling site and the total fishing duration was about one hour. The cast nets were hauled 15 times at each sampling site and the fishing duration was about $1.5 \mathrm{~h}$. The combination of these fishing gears was effective in sampling fishes of a wide range of species and sizes from different depth strata (Galib et al., 2018). All the fishing gears were operated over the same time on every sampling date to standardize the sampling effort. The fish abundance data gathered therefore represent Catch Per Unit Effort (CPUE), enabling the comparison of relative abundance between locations and dates. Individuals were identified to species and counted at the sampling sites. Specimens that were difficult to identify on site were preserved in $10 \%$ formaldehyde solution and brought to the laboratory for identification. Other fish sampled were returned to the river unharmed. Identification was made based on morphometric and meristic characters following Rahman (2005) and Talwar and Jhingran (1991). Scientific names and systematic positions of fishes follow those of Froese and Pauly (2017).

Reference to the global conservation status categories in this paper (e.g. Least Concern, Near Threatened, Vulnerable) are those in the online classification database developed by the International Union for the Conservation of Nature and Natural Resources (IUCN, 2018). National conservation categories are those published in the "Red List of Bangladesh" (IUCN Bangladesh, 2015).

Physico-chemical parameters (water temperature, water transparency, dissolved oxygen [DO], and $\mathrm{pH}$ ) were measured at each sampling point. Water temperature was measured by using a digital thermometer (Hanna), DO and $\mathrm{pH}$ were measured using portable water quality test kits $(\mathrm{HACH}$ Kit Box, Model FF1 and FF2; USA) and water transparency was measured using a Secchi disk. $\mathrm{pH}$ and DO tests remained consistent against laboratory calibrations; although $\mathrm{pH}$ was measured only with a precision of 0.5 of a $\mathrm{pH}$ unit, this was adequate to detect the substantial changes evident in the polluted zone.

\subsection{Data analysis}

The statistical software $\mathrm{R}$ was used to analyse the data (version 3.4.2; R Core Team, 2017), with an $\alpha$ level of significance of 0.05 . Linear mixed modelling (LMM) was employed to analyse repeated measures fish abundance and richness data using the "Imer" function of the "Ime4" package (Bates et al., 2014); $p$-values were obtained by the "lmerTest" package (Kuznetsova et al., 2016). During LMM location of the sampling sites, sampling years and their interaction were tested as fixed effects, and sampling sites and time were considered random effects. Least square means (i.e. marginal mean; Lenth, 2017) were also calculated to estimate the BACI contrast. Least square means are useful in the analysis of data for summarizing the effects of factors, and for testing linear contrasts among predictions including interaction contrasts like BA $\times$ CI (Schwarz, 2015; Lenth, 2017).

A Non-metric Multidimensional Scaling (NMDS; Kruskal and Wish, 1978) ordination plot was generated to visualize spatial and temporal variation of fishes using the "metaMDS" function of the "vegan" package (Oksanen et al., 2017). Fish CPUE abundance data were used to calculate Similarity Percentage Analysis (SIMPER), based on the decomposition of Bray-Curtis dissimilarity index (Clarke, 1993) was used to identify those native taxa that were most important in driving changes in species abundance among control and impacted sites.

Changes in water quality parameters were also analysed using LLMs outlined previously. The BIOENV procedure (Clarke and Ainsworth, 1993) was used to determine how well the patterns in water quality parameters correlated (Pearson's) with the changing assemblage patterns of fish (Boys et al., 2012). We ensured the exploration of data during analyses to avoid common statistical problems (Zuur et al., 2010). Before analysis data were checked for normality by Shapiro-Wilk test (Peat and Barton, 2005) and necessary transformations (square-root transformation for abundance data (McDonald, 2014) and log $(x+1)$ transformation for water quality data (Clarke, 1993)), were made to meet the statistical assumption for the tests. Normality of the model residuals were also checked with a q-q plot and no deviation from the linearity of the observations was observed.

\section{Results}

\subsection{Fish fauna}

In total, 60973 fish specimens belonging to 46 species, 35 genera and 18 families were collected and identified (Tab. 1). Three species (Sisor rabdophorus, Chaca chaca and Nandus nandus) were present in pre-waste outflow samples but were absent in 2016 samples (Tab. 1).

In the Barnoi River, the NMDS ordination plot shows similar species assemblages in the six sites sampled in 2006 (Fig. 2). In contrast, in 2016, three downstream sites $\left(\mathrm{S}_{4}-\mathrm{S}_{6}\right)$ showed a notable shift in assemblage composition from before to after the starting of the wastewater release into the river. A similar shift was not observed in the upstream sites $\left(\mathrm{S}_{1}-\mathrm{S}_{3}\right)$ over the same time period (Fig. 2). Although lower fish abundance and richness were observed at downstream sites in 2016, the difference was comparatively small from July to September but when the water level began to recede (September), the difference was more evident (Fig. 3).

\subsection{Fish abundance, species richness and water quality parameters in relation to waste dumping}

Levels of fish abundance (measured as CPUE) and fish species richness were similar between sampling sites before starting the waste dumping in the Barnoi River and reduced dramatically at the effluent-receiving downstream sites in recent times (Figs. 3 and 4). Significant variations in fish abundance and species richness (both $P \leq 0.001$ ) between sampling locations (upstream vs. downstream; CI) and period (before $v s$. after; BA) were evident from LLM results (Tab. 2). Interaction effects $(\mathrm{BA} \times \mathrm{CI})$ on fish abundance and species 
S.M. Galib et al.: Knowl. Manag. Aquat. Ecosyst. 2018, 419, 37

Table 1. Fish species caught at different locations (upstream; sites $S_{1}-S_{3}$; downstream; sites $S_{4}-S_{6}$ ) in the Barnoi River during the study period.

\begin{tabular}{|c|c|c|c|c|c|c|}
\hline Fish species & $\begin{array}{l}2006 \\
\text { Upstream }\end{array}$ & Downstream & $\begin{array}{l}2016 \\
\text { Upstream }\end{array}$ & Downstream & $\begin{array}{l}\text { Cons } \\
\mathrm{BD}^{\mathrm{a}}\end{array}$ & Global $^{\mathrm{b}}$ \\
\hline Belonidae & & & & & & \\
\hline $\begin{array}{l}\text { Xenentodon cancila } \\
\text { Clupeidae }\end{array}$ & 296 & 300 & 204 & 143 & $\mathrm{LC}$ & $\mathrm{LC}$ \\
\hline Gudusia chapra & 403 & 437 & 456 & 252 & VU & $\mathrm{LC}$ \\
\hline $\begin{array}{l}\text { Corica soborna } \\
\text { Engraulidae }\end{array}$ & 275 & 201 & 138 & 26 & $\mathrm{LC}$ & $\mathrm{LC}$ \\
\hline $\begin{array}{l}\text { Setipinna phasa } \\
\text { Cyprinidae }\end{array}$ & 281 & 241 & 137 & 30 & $\mathrm{LC}$ & $\mathrm{LC}$ \\
\hline Amblypharyngodon mola & 1145 & 1279 & 1371 & 779 & $\mathrm{LC}$ & $\mathrm{LC}$ \\
\hline Aspidoparia morar & 199 & 224 & 88 & 3 & VU & $\mathrm{LC}$ \\
\hline Cirrhinus mrigala & 109 & 131 & 54 & 4 & NT & $\mathrm{LC}$ \\
\hline Cirrhinus reba & 170 & 187 & 147 & 46 & NT & $\mathrm{LC}$ \\
\hline Esomus danricus & 391 & 401 & 318 & 43 & $\mathrm{LC}$ & $\mathrm{LC}$ \\
\hline Labeo bata & 276 & 264 & 193 & 21 & $\mathrm{LC}$ & $\mathrm{LC}$ \\
\hline Labeo rohita & 177 & 187 & 121 & 4 & $\mathrm{LC}$ & $\mathrm{LC}$ \\
\hline Puntius chola & 502 & 494 & 588 & 152 & $\mathrm{LC}$ & $\mathrm{LC}$ \\
\hline Puntius sophore & 2118 & 2136 & 2248 & 1111 & $\mathrm{LC}$ & $\mathrm{LC}$ \\
\hline Puntius ticto & 239 & 267 & 152 & 56 & VU & $\mathrm{LC}$ \\
\hline Salmostoma phulo & 719 & 796 & 812 & 445 & NT & $\mathrm{LC}$ \\
\hline Cobitidae & & & & & & \\
\hline Botia dario & 287 & 225 & 218 & 42 & EN & $\mathrm{LC}$ \\
\hline Botia lohachata & 80 & 64 & 47 & 30 & EN & $\mathrm{NE}$ \\
\hline $\begin{array}{l}\text { Lepidocephalichthys } \\
\text { guntea }\end{array}$ & 567 & 513 & 515 & 389 & $\mathrm{LC}$ & $\mathrm{LC}$ \\
\hline Bagridae & & & & & & \\
\hline Mystus cavasius & 435 & 444 & 413 & 282 & NT & $\mathrm{LC}$ \\
\hline Mystus tengara & 1057 & 1046 & 1018 & 772 & $\mathrm{LC}$ & $\mathrm{LC}$ \\
\hline Mystus vittatus & 283 & 282 & 179 & 57 & $\mathrm{LC}$ & $\mathrm{LC}$ \\
\hline Rita rita & 269 & 268 & 239 & 48 & $\mathrm{EN}$ & $\mathrm{LC}$ \\
\hline Sperata seenghala & 238 & 235 & 75 & 20 & VU & $\mathrm{LC}$ \\
\hline Chacidae & & & & & & \\
\hline Chaca chaca & 21 & 9 & 0 & 0 & EN & $\mathrm{LC}$ \\
\hline Schilbeidae & & & & & & \\
\hline Ailia coila & 553 & 643 & 544 & 111 & $\mathrm{LC}$ & NT \\
\hline Clupisoma garua & 345 & 329 & 210 & 19 & $\mathrm{EN}$ & $\mathrm{LC}$ \\
\hline Eutropiichthys vacha & 322 & 327 & 215 & 7 & $\mathrm{LC}$ & $\mathrm{LC}$ \\
\hline Pachypterus atherinoides & 438 & 404 & 276 & 102 & $\mathrm{LC}$ & $\mathrm{NE}$ \\
\hline Siluridae & & & & & & \\
\hline Ompok bimaculatus & 170 & 158 & 131 & 5 & EN & NT \\
\hline Wallago attu & 71 & 59 & 24 & 3 & VU & NT \\
\hline Sisoridae & & & & & & \\
\hline Gagata cenia & 410 & 441 & 512 & 91 & $\mathrm{LC}$ & $\mathrm{LC}$ \\
\hline Sisor rabdophorus & 8 & 4 & 0 & 0 & $\mathrm{CR}$ & $\mathrm{LC}$ \\
\hline Ambassidae & & & & & & \\
\hline Chanda nama & 1053 & 977 & 1377 & 1104 & $\mathrm{LC}$ & $\mathrm{LC}$ \\
\hline Parambassis lala & 92 & 79 & 90 & 129 & $\mathrm{LC}$ & NT \\
\hline Parambassis ranga & 1094 & 1009 & 1189 & 949 & $\mathrm{LC}$ & $\mathrm{LC}$ \\
\hline Anabantidae & & & & & & \\
\hline $\begin{array}{l}\text { Anabas testudineus } \\
\text { Channidae }\end{array}$ & 191 & 214 & 103 & 73 & $\mathrm{LC}$ & $\mathrm{DD}$ \\
\hline Channa punctata & 197 & 209 & 92 & 59 & LC & LC \\
\hline Channa striata & 56 & 83 & 12 & 2 & $\mathrm{LC}$ & $\mathrm{LC}$ \\
\hline
\end{tabular}


Table 1. (continued).

\begin{tabular}{|c|c|c|c|c|c|c|}
\hline \multirow[t]{2}{*}{ Fish species } & \multirow{2}{*}{$\begin{array}{l}2006 \\
\text { Upstream }\end{array}$} & \multirow[b]{2}{*}{ Downstream } & \multicolumn{2}{|l|}{2016} & \multicolumn{2}{|c|}{ Conservation } \\
\hline & & & Upstream & Downstream & $\mathrm{BD}^{\mathrm{a}}$ & Global $^{\mathrm{b}}$ \\
\hline \multicolumn{7}{|l|}{ Gobiidae } \\
\hline Glossogobius giuris & 836 & 876 & 872 & 329 & $\mathrm{LC}$ & $\mathrm{LC}$ \\
\hline \multicolumn{7}{|l|}{ Nandidae } \\
\hline Nandus nandus & 74 & 52 & 0 & 0 & NT & $\mathrm{LC}$ \\
\hline \multicolumn{7}{|l|}{ Osphronemidae } \\
\hline Trichogaster fasciata & 499 & 541 & 440 & 560 & $\mathrm{LC}$ & $\mathrm{LC}$ \\
\hline Trichogaster lalius & 126 & 147 & 91 & 205 & $\mathrm{LC}$ & $\mathrm{LC}$ \\
\hline \multicolumn{7}{|l|}{ Sciaenidae } \\
\hline Otolithoides pama & 66 & 62 & 43 & 0 & $\mathrm{LC}$ & NE \\
\hline \multicolumn{7}{|l|}{ Mastacembelidae } \\
\hline Macrognathus aculeatus & 109 & 100 & 30 & 2 & NT & NE \\
\hline Macrognathus pancalus & 347 & 353 & 262 & 116 & $\mathrm{LC}$ & $\mathrm{LC}$ \\
\hline Mastacembelus armatus & 282 & 270 & 206 & 58 & EN & $\mathrm{LC}$ \\
\hline
\end{tabular}

BD, Bangladesh; CR, critically endangered; EN, endangered; LC, least concern; NE, not evaluated; NT, near threatened; VU, vulnerable.

${ }^{a}$ as per IUCN Bangladesh (2015).

b IUCN (2018).

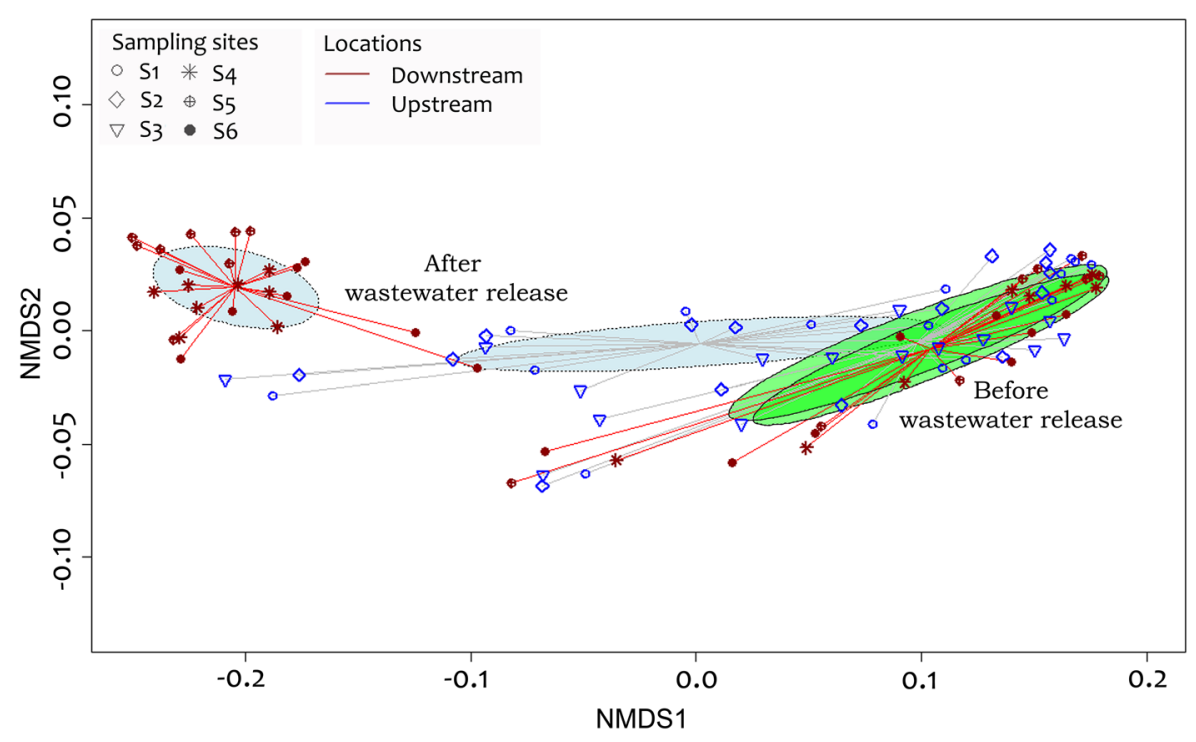

Fig. 2. Non-metric multidimensional scaling (NMDS) ordination plot showing spatial and temporal variations of fish abundance in relation to wastewater release into the Barnoi River.

richness were also significant (all $P<0.001$; Tab. 2). Least square means also indicated that both fish species richness and their abundance reduced at the downstream sites in recent times compared to other combinations (i.e. vs. $\mathrm{CB}$ or IB or $\mathrm{CA}$; Tab. 2).

Similar to fish abundance and species richness, patterns of different physico-chemical parameters of water, except water temperature, also varied significantly over time (before vs. after) and space (upstream vs. downstream) (all $P<0.01$; Fig. 5; Tab. 2). Least square means also indicated that $\mathrm{pH}, \mathrm{DO}$ and water transparency reduced at the downstream sites in recent times compared to other combinations (i.e. vs. $\mathrm{CB}$ or IB or CA Tab. 2).
BIOENV analysis revealed that $\mathrm{DO}$ and $\mathrm{pH}$ collectively were strongly correlated with the fish assemblage patterns observed in the Barnoi River $(\rho=0.731)$, and showed a significant response to waste dumping practices in the river (Tab. 2). There was an overall decrease in both $\mathrm{DO}$ and $\mathrm{pH}$ from before to after wastewater release across all sampling sites receiving waste waters $\left(\mathrm{S}_{4}-\mathrm{S}_{6}\right)$ when compared to upstream sites $\left(\mathrm{S}_{1}-\mathrm{S}_{3}\right)$.

SIMPER test results (Tabs. S1-S4) revealed that the CPUE of only four native fish species (Wallago attu, C. chaca, $S$. rabdophorus and $N$. nandus) varied significantly $(P<0.05)$ between upstream and downstream sites before wastewater releases (Tab. S1). Subsequent to wastewater releases, the 


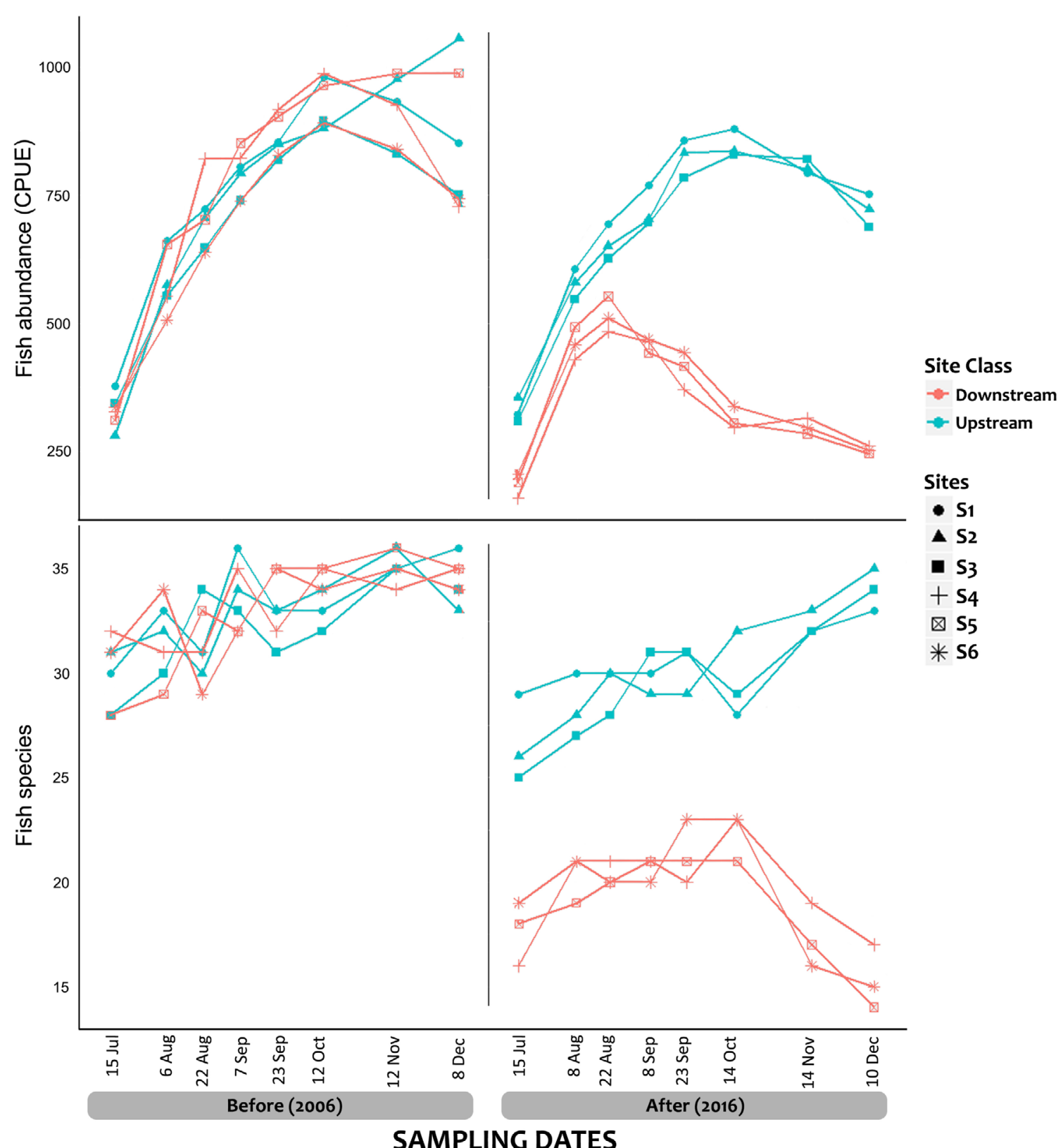

Fig. 3. Fish abundance (as CPUE) and species richness over time at different sites in the Barnoi River. Before and After refer to data gathered prior to and after the commencement of wastewater release in the middle part of the study section.

abundance of 25 species varied significantly $(P<0.05)$ between upstream and downstream sites and 16 species contributed $>70 \%$ of the dissimilarity in fish assemblages (Tab. S2). Again, assemblages at the downstream sites $\left(\mathrm{S}_{4}-\mathrm{S}_{6}\right)$ varied widely between time periods where 39 species $(84.8 \%$ of the total species) varied significantly $(P<0.05$; Tab. S3) whereas no significant temporal changes, except for one species ( $N$. nandus), were observed in upstream sites (Tab. S4). In this case 21 native taxa contributed $>70 \%$ of the dissimilarity in fish abundance. The majority of the indigenous taxa contributing to the dissimilarity among upstream vs. downstream [in 2016] and between downstream sites over time (2006 vs. 2016) were small indigenous species (Tabs. S2-S4).

\subsection{Threatened taxa}

Nineteen species (41.3\% of all species) recorded in the present study are classed as of conservation concern in Bangladesh (critically endangered, one sp.; endangered, seven spp.; vulnerable, five spp.; near threatened, six spp.; Tab. 1). Among these, three species, between time periods, were absent in post-wastewater release (2016) catches, both downstream and upstream of the wastewater inputs. Otolithoides pama was absent downstream of the wastewater input in 2016, but present upstream. Among remaining threatened fish species $(n=16)$, abundance of all but one species (Botia lohachata) decreased significantly $(P<0.05)$ at the downstream sites following wastewater releases (Tab. S3). Similar to overall fish 
S.M. Galib et al.: Knowl. Manag. Aquat. Ecosyst. 2018, 419, 37

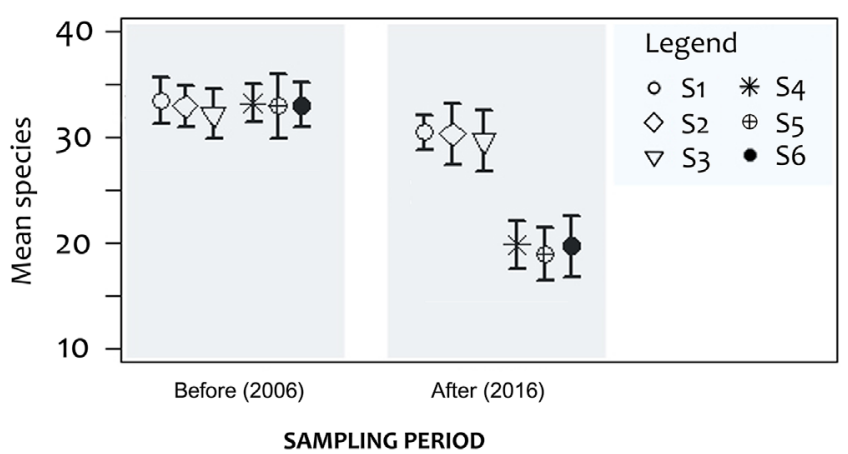

Fig. 4. Number of fish species (mean $\pm \mathrm{SD}$ ) occurring at each sampling site in relation to wastewater release (before, 2006, during, 2016) in the Barnoi River.

Table 2. BACI comparisons of fish assemblages and physicochemical parameters of water in the Barnoi River at various times from before to after waste dumping, obtained through linear mixedeffects modelling.

\begin{tabular}{|c|c|c|c|}
\hline Factors & $F$ & $P$ & LSmeans \\
\hline \multicolumn{4}{|l|}{ Fish abundance } \\
\hline Before-After (BA) & 6.60 & 0.022 & \\
\hline Upstream-Downstream (CI) & 94.0 & 0.001 & \\
\hline $\mathrm{BA} \times \mathrm{CI}$ & 119.61 & $<0.001$ & \\
\hline Upstream-Before (CB) & & & 5.181 \\
\hline Downstream-Before (IB) & & & 5.182 \\
\hline Upstream-After (CA) & & & 5.083 \\
\hline Downstream-After (IA) & & & 4.319 \\
\hline \multicolumn{4}{|l|}{ Fish species richness } \\
\hline Before-After (BA) & 123.84 & $<0.001$ & \\
\hline Upstream-Downstream (CI) & 170.27 & $<0.001$ & \\
\hline $\mathrm{BA} \times \mathrm{CI}$ & 181.80 & $<0.001$ & \\
\hline Upstream-Before (CB) & & & 5.723 \\
\hline Downstream-Before (IB) & & & 5.741 \\
\hline Upstream-After (CA) & & & 5.480 \\
\hline Downstream-After (IA) & & & 4.397 \\
\hline \multicolumn{4}{|c|}{ Abundance of locally threatened spp. } \\
\hline Before-After (BA) & 18.42 & $<0.001$ & \\
\hline Upstream-Downstream (CI) & 72.09 & $<0.001$ & \\
\hline $\mathrm{BA} \times \mathrm{CI}$ & 19.60 & $<0.001$ & \\
\hline Upstream-Before (CB) & & & 222.526 \\
\hline Downstream-Before (IB) & & & 224.158 \\
\hline Upstream-After (CA) & & & 173.789 \\
\hline Downstream-After (IA) & & & 69.211 \\
\hline \multicolumn{4}{|l|}{$\mathrm{pH}$} \\
\hline Before-After (BA) & 183.54 & $<0.001$ & \\
\hline Upstream-Downstream (CI) & 63.21 & 0.001 & \\
\hline $\mathrm{BA} \times \mathrm{CI}$ & 370.50 & $<0.001$ & \\
\hline Upstream-Before (CB) & & & 6.938 \\
\hline Downstream-Before (IB) & & & 7.083 \\
\hline Upstream-After (CA) & & & 6.854 \\
\hline Downstream-After (IA) & & & 4.813 \\
\hline
\end{tabular}

Table 2. (continued).

\begin{tabular}{|c|c|c|c|}
\hline Factors & $F$ & $P$ & LSmeans \\
\hline \multicolumn{4}{|l|}{ Dissolved oxygen } \\
\hline Before-After (BA) & 61.40 & $<0.001$ & \\
\hline Upstream-Downstream (CI) & 1194.90 & $<0.001$ & \\
\hline $\mathrm{BA} \times \mathrm{CI}$ & 1260.30 & $<0.001$ & \\
\hline Upstream-Before (CB) & & & 5.168 \\
\hline Downstream-Before (IB) & & & 5.194 \\
\hline Upstream-After (CA) & & & 5.045 \\
\hline Downstream-After (IA) & & & 3.106 \\
\hline \multicolumn{4}{|l|}{ Water temperature } \\
\hline Before-After (BA) & 1.72 & 0.211 & \\
\hline Upstream-Downstream (CI) & 0.46 & 0.501 & \\
\hline $\mathrm{BA} \times \mathrm{CI}$ & 0.47 & 0.499 & \\
\hline Upstream-Before (CB) & & & 24.646 \\
\hline Downstream-Before (IB) & & & 24.500 \\
\hline Upstream-After (CA) & & & 26.209 \\
\hline Downstream-After (IA) & & & 26.208 \\
\hline \multicolumn{4}{|l|}{ Water transparency } \\
\hline Before-After (BA) & 11.28 & 0.005 & \\
\hline Upstream-Downstream (CI) & 170.34 & $<0.001$ & \\
\hline $\mathrm{BA} \times \mathrm{CI}$ & 203.10 & $<0.001$ & \\
\hline Upstream-Before (CB) & & & 31.500 \\
\hline Downstream-Before (IB) & & & 32.167 \\
\hline Upstream-After (CA) & & & 33.083 \\
\hline Downstream-After (IA) & & & 17.917 \\
\hline
\end{tabular}

abundance and species richness patterns, abundance of species considered threatened in Bangladesh followed the same temporal and spatial variations, with a lower number of individuals at impacted sites (Tab. 2). Four species (Ailia coila, Ompok bimaculatus, W. attu and Parambassis lala) were also on the IUCN redlist of globally threatened species (ranked as Near Threatened; Tab. 1). However, out of 27 non threatened species, the abundance of 24 also decreased significantly $(P<0.05)$ at downstream sites following wastewater releases (Tab. S3).

\section{Discussion}

\subsection{Spatial and temporal changes in fish community and water quality}

This study provides evidence of the impact of wastewater on the fish community and some water quality parameters in the Barnoi River. As predicted, in sites receiving wastewater declines in species abundance $(>51 \%)$ and species richness $(>41 \%)$ were recorded. Over the same time, fish abundance and richness at upstream sites declined slightly by $\sim 8 \%$. Downstream wastewater-impacted sites supported much lower fish abundance (by $>47 \%$ ) and species richness (by $>35 \%$ ) compared to unaffected upstream sites. Similar significant changes in $\mathrm{pH}, \mathrm{DO}$ and water transparency were also observed. 

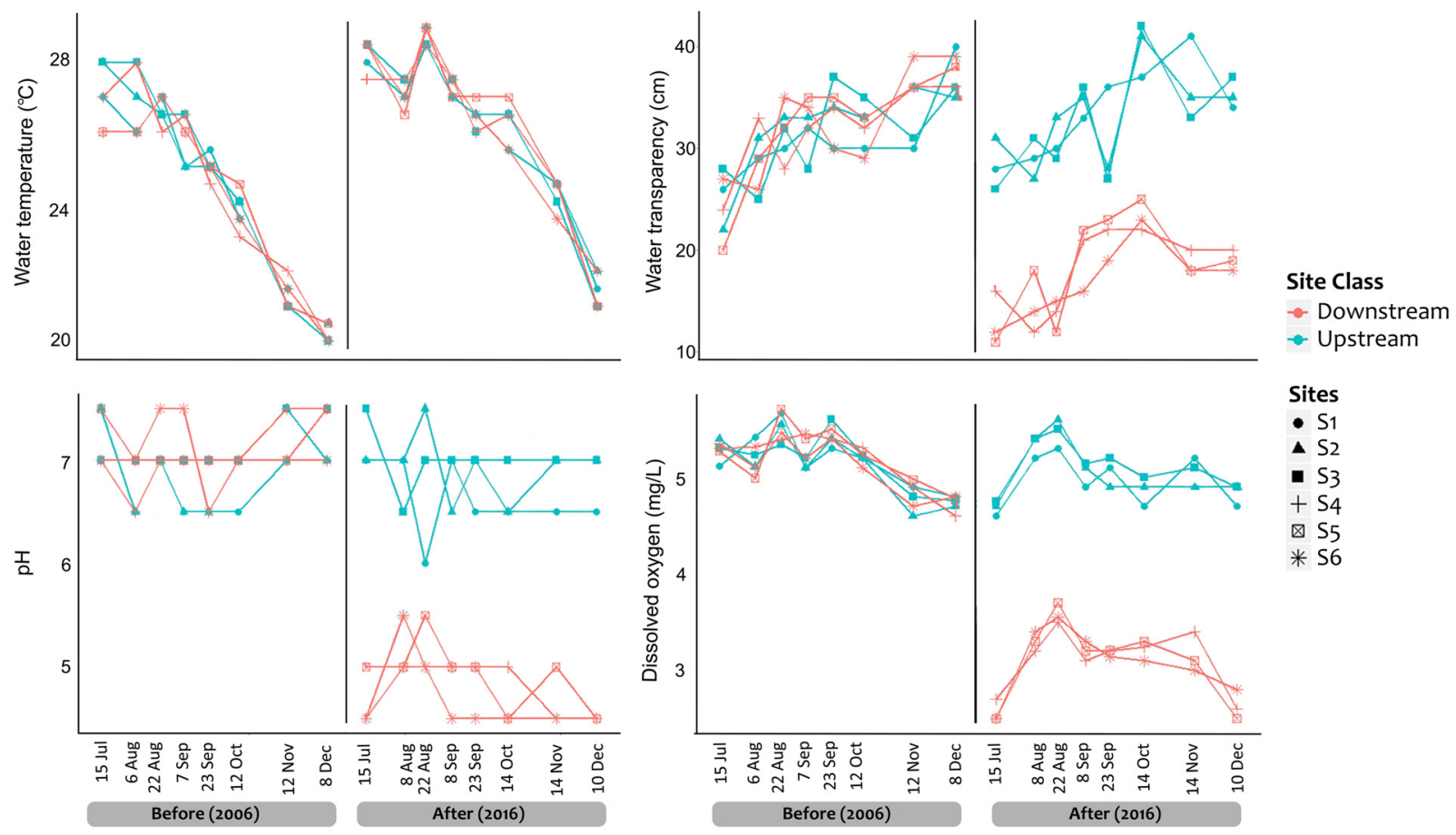

\section{SAMPLING DATES}

Fig. 5. Spatial and temporal variations in different physico-chemical parameters over time and space in the Barnoi River.

These changes were clearly a result of wastewater discharge, as similar changes were not observed in un-affected upstream sites.

Severe organic pollution can result in an elimination of fishes for long distances but they often disappear from the impacted area without apparently being killed (Hynes, 1963). As fishes are extremely mobile (Boys et al., 2012; Cooke et al., 2016) and can move to new localities rapidly (Peterson and Bayley, 1993; Sheldon and Meffe, 1995), fish populations in the downstream sites of the river might have moved to unimpacted upstream sites or further downstream to a more suitable area. However, some species, especially those with accessory respiratory organs (i.e. air-breathing fishes) may still survive in habitats with poor water quality (Ip et al., 2004; Lefevre et al., 2014). In Bangladesh air-breathing fishes include catfishes (Siluriformes), labyrinth fishes (Anabantoidea), spiny eels (Mastacelembidae) and snakeheads (Channidae) (Rahman, 2005; Hasan and Mohsin, 2010) and these species (e.g. Anabas testudineus, Channa punctata and Channa striata) were among the few species whose abundance did not vary significantly $(P>0.05)$ between upstream and downstream sites in 2016 despite wastewater release (Tab. S2).

Although lower numbers of individuals and species were observed in downstream sites in 2016 this difference was comparatively smaller from July to September than in other months. This might be due to the rise in water level associated with heavy rains during the rainy season (Galib et al., 2016, 2018) that may reduce the level of unfavourable physicochemical properties of water through pollutant dilution (Kumar and Reddy, 2009). When the water level began to recede, the impact of wastewater pollution on fish abundance and species richness became much more apparent. Evidence of similar impacts of wastewater on zooplankton, the key natural food for many of the fishes, during low water level is available (Deksne, 2011).

Observed patterns of fish population abundance in the Barnoi were strongly correlated with $\mathrm{DO}$ and $\mathrm{pH}$ - two vital physico-chemical parameters for aquatic life. The influences of wastewater on these parameters are well documented (e.g. Hynes, 1963; Mason, 2001; Sepulveda-Jauregui et al., 2013). Temporal patterns of DO, $\mathrm{pH}$ and water transparency in this study are clear signs of organic pollution (Allan et al., 1958; Hynes, 1963). Although BIOENV results showed that the DO and $\mathrm{pH}$ collectively were strongly correlated with the changing patterns of the fish assemblage, reduced water transparency can also impact fish populations in various ways. Spawning and feeding efficiencies of fishes may be seriously affected by suspended matter produced through organic pollution in water (Hynes, 1963) as reported by the fishermen in the study area. In addition, it also reduces light availability to photosynthetic organisms that may result in reduced primary productivity of the habitat (Mason, 2001). However, accumulation of fine, grey sludge on the leaves of aquatic macrophyte in the impacted downstream sites also indicates effects of organic pollution that may seriously impact the aquatic vegetation and thus may make the habitat less suitable for other aquatic animals. The overall impacts of untreated wastewater release on fishes in the Barnoi are therefore likely a combination of direct water quality effects and indirect effects on the habitat, particularly on vegetation and food sources (Hynes, 1963; Mason, 2001). 


\subsection{Conservation implications}

Serving as a channel that connects with several water bodies (Manda floodplain, Atrai River, Baral River, Chalan Beel and others) the Barnoi is ecologically vital for sustaining not only fishes but also other organisms. But wastewater releases in the impacted location (i.e. downstream sites) may have caused a functional disconnection by making the habitat unfavourable, reducing longitudinal movement of fish and leading to local extinction of migratory aquatic organisms (Warren and Pardew, 1998; Cooke et al., 2016). Fish abundance and diversity were greater in upstream sites; however, the effect of wastewater outflow on river water quality has virtually isolated these habitats (primarily its origin, Manda floodplain) from other floodplains and rivers including the country's largest wetland. This imposes a serious threat to biota in isolated parts of the river system making them more susceptible to local extinctions.

The complete absence of three species in 2016 sampling (both upstream and downstream of the wastewater outflow) indicates that these species (C. chaca, S. rabdophorus and $N$. nandus), all bottom dwellers and of high conservation importance in Bangladesh (IUCN Bangladesh, 2015), have possibly become extinct from the study area. This might be due, in part, to existing wastewater releases in the Barnoi. Bottom dwelling fishes are very susceptible to anthropogenic river pollution that can damage their DNA and fatty acid profiles (Hussain et al., 2017) and other physiological functions including reproduction (Jessica et al., 2007; Nogueira et al., 2011; Palanisamy et al., 2011; Lenhardt et al., 2012). The absence of these species from cleaner-water sites upstream of the wastewater suggests that stochastic factors acting on the more isolated populations upstream might have depleted populations too.

\subsection{Implications for current wastewater management and further research}

The current management practice for wastes or industrial effluents in Bangladesh, as well as in other developing countries, is similar (e.g. Girija et al., 2007; Omosa et al., 2012; Haque, 2017) - draining them out into the nearby waters, usually rivers, usually without any prior treatment $(e . g$. Dudgeon, 2000). This is primarily because the majority of the industries do not have a proper treatment plant or plants have been kept idle to reduce operating costs (Omosa et al., 2012; Haque, 2017). Thus similar results can also be expected in other developing countries where wastewaters are being drained into the nearby water bodies without any prior treatment. To minimise this impact, wastewater should be treated through establishing proper treatment plants. However, treated effluents can also be dangerous to the receiving water bodies (Kumar and Reddy, 2009) and thus multiple treatments might be considered before releasing wastewater into natural water bodies.

This study also showed that not only traditional pollutants or effluents (from industrial, agricultural, municipal etc. sources) are finding their way into the rivers with wastewaters but also waste products from pharmacies and clinics are being dumped into the waste channels. Pharmaceutical effluents can result in endocrine disruption in fishes, reduced abundance and a lack of sensitive fish species (Sanchez et al., 2011). There is a high potential for accumulation of antibiotics, chemical and biological agents (including harmful pathogens) in the river water in the study area that can be a significant threat to all animals including fish and humans (Kümmerer, 2001; Brown et al., 2006; Fent et al., 2006). This practice must be stopped and proper waste management (incineration of medical and pharmaceutical waste) should be introduced. Another important source of water quality degradation in the studied river was dumping of large-sized dead animals (cattle, goats and buffalo) that requires huge amounts of DO for its decomposition i.e. biological oxygen demand (BOD) would be much higher and results in lower DO and higher dissolved carbon dioxide (Mason, 2001). Again, regulation needs to be enforced so that these dead livestock are disposed of properly, without increased pollution risk.

The broken sluices found in this study must be repaired to stop continuous flow of wastewater into the river and natural biological treatment should be considered using locally available aquatic macrophytes (e.g. common reeds, water hyacinths and duckweeds) that can effectively remove nutrients and heavy metals from wastewaters (O'Hogain and Gray, 2002; Nielsen and Willoughby, 2005; Rezania et al., 2015). However, care should be taken if floating macrophytes are used as these may cover the water surface and restrict sunlight penetration. A reed (Phragmites spp.) bed treatment approach is likely to be the best option, provided that screens are used to remove large debris and most solid organic waste first. Reed bed treatment is a common, cost-effective and environmentally friendly method used for filtering water and removing suspended sediments, organic materials and metals worldwide (O'Hogain and Gray, 2002; Nielsen and Willoughby, 2005; Uggetti et al., 2012). Considering the floodplain topography of the study area, a horizontal reed-bed system (into which the canals run, before release to the river) is suggested.

If in future, wastewater is treated, research should be carried out to determine the success from a biodiversity standpoint using fish species that are most responsive (e.g. Puntius sophore, Chanda nama, Amblypharyngodon mola and Parambassis ranga, Glossogobius giuris; a list of more responsive species is available in Tab. S2) to wastewater in the Barnoi River. Alongside this, improvements in physicochemical parameters of river water should be monitored continuously.

Acknowledgements. We thank the reviewers for helpful comments and suggestions that improved the manuscript.

\section{References}

Ahmed MK, Baki MA, Islam MS, et al. 2015. Human health risk assessment of heavy metals in tropical fish and shellfish collected from the river Buriganga, Bangladesh. Environ Sci Pollut Res 22: 15880-15890.

Ali MM, Alia ML, Islam MS, Rahman MZ. 2016. Preliminary assessment of heavy metals in water and sediment of Karnaphuli River, Bangladesh. Environ Nanotechnol Monit Manag 5: 27-35. 
Allan IRH, Herbert DWM, Alabaster JS. 1958. A field and laboratory investigation of fish in a sewage effluent. Fish Invest Lond 6: 76.

Bashar MA, Salam MA, Kamal MM, Siddique MAB, Mofasshalin MS. 2009. Present biodiversity status of freshwater catfishes at the Barnai river of Rajshahi district. J Agrofor Environ 3: 137-142.

Bates D, Mächler M, Bolker B, Walker S. 2014. Fitting linear mixedeffects models using lme4. J Stat Softw 67: 1-51.

Bhuyan MS, Bakar MA. 2017. Seasonal variation of heavy metals in water and sediments in the Halda River, Chittagong, Bangladesh. Environ Sci Pollut Res 24: 27587-27600.

Boys CA, Kroon FJ, Glasby TM, Wilkinson K. 2012. Improved fish and crustacean passage in tidal creeks following floodgate remediation. J Appl Ecol 49: 223-233.

Brown KD, Kulis J, Thomson B, Chapman TH, Mawhinney DB. 2006. Occurrence of antibiotics in hospital, residential, and dairy effluent, municipal wastewater, and the Rio Grande in New Mexico. Sci Total Environ 366: 772-783.

Clarke KR. 1993. Non-parametric multivariate analyses of changes in community structure. Aust $J$ Ecol 18: 117-143.

Clarke KR, Ainsworth M. 1993. A method of linking multivariate community structure to environmental variables. Mar Ecol Prog Ser 92: 205-219.

Cooke SJ, Martins EG, Struthers DP, et al. 2016. A moving target incorporating knowledge of the spatial ecology of fish into the assessment and management of freshwater fish populations. Environ Monit Assess 188: 239.

Dai L, Wang L, Li L, et al. 2018. Multivariate geostatistical analysis and source identification of heavy metals in the sediment of Poyang Lake in China. Sci Total Environ 621: 1433-1444.

Deksne R. 2011. Influence of wastewater on zooplankton communities in the Daugava River upstream and downstream of Daugavpils over the last 50 years. Knowl Manag Aquat Ecosyst 402: 07.

Dirzo R, Young HS, Galetti M, Ceballos G, Isaac NJB, Collen B. 2014. Defaunation in the anthropocene. Science 345: 401-406.

Downes BJ, Barmuta LA, Fairweather PG, et al. 2002. Monitoring ecological impacts: concepts and practice in flowing waters. Cambridge: Cambridge University Press, $452 \mathrm{p}$.

Dudgeon D. 1992. Endangered ecosystems: a review of the conservation status of tropical Asian rivers. Hydrobiologia 248: 167-191.

Dudgeon D. 2000. Large-scale hydrological changes in tropical Asia: prospects for riverine biodiversity. BioScience 50: 793-806.

Dudgeon D. 2002. Fisheries: pollution and habitat degradation in tropical Asian rivers. In: Douglas I, ed. Encyclopedia of global environmental change Vol. III, Chichester (UK): Wiley, pp. 316-323.

Dudgeon D. 2005. River rehabilitation for conservation of fish biodiversity in monsoonal Asia. Ecol Soc 10: 15.

Dudgeon D, Arthington AH, Gessner MO, et al. 2006. Freshwater biodiversity: importance, threats, status and conservation challenges. Biol Rev Camb Philos Soc 81: 163-182.

Fent K, Weston AA, Caminada D. 2006. Ecotoxicology of human pharmaceuticals. Aquat Toxicol 76: 122-159.

Froese R, Pauly D. 2017. FishBase. World Wide Web electronic publication. www.fishbase.org, version (10/2017).

Galib SM, Rashid MA, Chaki N, Mohsin ABM, Joadder MAR. 2016. Seasonal variation and community structure of fishes in the Mahananda River with special reference to conservation issues. J Fish 4: 325-334.
Galib SM, Lucas MC, Chaki N, Fahad FH, Mohsin ABM. 2018. Is current floodplain management a cause for concern for fish and bird conservation in Bangladesh's largest wetland? Aquat Conserv Mar Freshw Ecosyst 28: 98-114.

Girija TR, Mahanta C, Chandramouli V. 2007. Water quality assessment of an untreated effluent impacted urban stream: the Bharalu Tributary of the Brahmaputra River, India. Environ Monit Assess 130: 221-236.

Hasan MM, Mohsin ABM. 2010. Freshwater air-breathing fishes of north-west Bangladesh: species and organ diversity. Thesis, Department of Fisheries, University of Rajshahi, Bangladesh, 85 p.

Haque N. 2017. Exploratory analysis of fines for water pollution in Bangladesh. Water Resour Ind 18: 1-8.

Hussain MG. 2010. Freshwater fishes of Bangladesh: fisheries, biodiversity and habitat. Aquat Ecosyst Health Manag 13: 85-93.

Hussain B, Sultana T, Sultana S, Al-Ghanim KA, Mahboob S. 2017. Effect of pollution on DNA damage and essential fatty acid profile in Cirrhinus mrigala from River Chenab. Chin J Oceanol Limnol 35: $572-579$.

Hynes HBN. 1963. The biology of polluted waters. Liverpool: Liverpool University Press.

Ip Y, Chew S, Wilson J, Randall D. 2004. Defences against ammonia toxicity in tropical air-breathing fishes exposed to high concentrations of environmental ammonia: a review. J Comp Physiol B 174: 565-575.

Islam MS, Ahmed MK, Habibullah-Al-Mamuna M, Masunagaaa S. 2015. Assessment of trace metals in fish species of urban rivers in Bangladesh and health implications. Environ Toxicol Pharmacol 39: 347-357.

IUCN Bangladesh. 2015. Red list of Bangladesh: a brief on assessment result 2015. In: IUCN, International Union for Conservation of Nature, Dhaka, (Bangladesh): Bangladesh Country Office, $24 \mathrm{p}$.

IUCN. 2018. The IUCN Red List of Threatened Species. Version 2017-3. <www.iucnredlist.org > . Downloaded on 02 March 2018.

Jessica D, Robert M, Frédéric S, et al. 2007. Do sewage treatment plant discharges substantially impair fish reproduction in polluted rivers? Sci Total Environ 372: 497-514.

Karaouzas I, Smeti E, Vourka A, et al. 2018. Assessing the ecological effects of water stress and pollution in a temporary river - implications for water management. Sci Total Environ 618: 1591-1604.

Keesing F, Belden LK, Daszak, et al. 2010. Impacts of biodiversity on the emergence and transmission of infectious diseases. Nature 468: $647-652$.

Kibria G, Hossain MM, Mallick D, Lau TC, Wu R. 2016. Monitoring of metal pollution in waterways across Bangladesh and ecological and public health implications of pollution. Chemosphere 165: 1-9.

Kruskal JB, Wish M. 1978. Multidimensional scaling. London: Sage Publications, $96 \mathrm{p}$.

Kumar AY, Reddy MV. 2009. Assessment of seasonal effects of municipal sewage pollution on the water quality of an urban canal - a case study of the Buckingham canal at Kalpakkam (India): $\mathrm{NO}_{3}, \mathrm{PO}_{4}, \mathrm{SO}_{4}, \mathrm{BOD}, \mathrm{COD}$ and DO. Environ Monit Assess 157: 223-234.

Kümmerer K. 2001. Drugs in the environment: emission of drugs, diagnostic aids and disinfectants into wastewater by hospitals in relation to other sources - a review. Chemosphere 45: 957-969.

Kuznetsova A, Brockhoff PB, Christensen RHB. 2016. 1merTest: Tests in Linear Mixed Effects Models. R package version 2. 0-33. https://CRAN.R-project.org/package=lmerTest. 
Lefevre S, Bayley M, Mckenzie DJ, Craig JF. 2014. Air breathing fishes. J Fish Biol 84: 547-553.

Lenhardt M, Jarić I, Višnjić-Jeftić Ž, et al. 2012. Concentrations of 17 elements in muscle, gills, liver and gonads of five economically important fish species from the Danube River. Knowl Manag Aquat Ecosyst 407: 02.

Lenth RV. 2017. Using 1smeans. https://cran.r-project.org/web/pack ages/lsmeans/vignettes/using-lsmeans.pdf

Mason CF. 2001. Biology of Freshwater Pollution, 4th ed. New Jersey: Prentice Hall, 400 p.

McDonald JH. 2014. Handbook of Biological Statistics, 3rd ed. Maryland: Sparky House Publishing, 287 p.

Meybeck M. 2004. The global change of continental aquatic systems: dominant impacts of human activities. Water Sci Technol 49, 73-83.

Morse JC, Bae YJ, Munkhjargal G, et al. 2007. Freshwater biomonitoring with macroinvertebrates in East Asia. Front Ecol Environ 5: 33-42.

Moss B. 1998. Ecology of fresh waters: man and medium, past to future. Oxford: Blackwell Science, $572 \mathrm{p}$.

Moss B. 2008. Water pollution by agriculture. Philos Trans $R$ Soc $B$ 363: 659-666.

Mulk S, Latif A, Azizullah K, Muhammad A, Khattak NK. 2016. Decreased fish diversity found near marble industry effluents in River Barandu, Pakistan. Ecotoxicology 25: 132-140.

Nielsen S, Willoughby N. 2005. Sludge treatment and drying reed bed systems in Denmark. Water Environ J 19: 296-305.

Nogueira L, Rodrigues ACF, Trídico CP, Fossa CE, Almeida EA. 2011. Oxidative stress in Nile tilapia (Oreochromis niloticus) and armored catfish (Pterygoplichthys anisitsi) exposed to diesel oil. Environ Monit Assess 180: 243-255.

O'Hogain S, Gray NF. 2002. Colecott hybrid reed-bed treatment system: design, construction and operation. Water Environ $J$ 16: 90-95.

Oksanen J, Blanchet FG, Friendly M, et al. 2017. Vegan: community ecology package. $\mathrm{R}$ package version 2.4-3. https://CRAN.Rproject.org/package=vegan.

Omosa IB, Wang H, Cheng S, Li F. 2012. Sustainable tertiary wastewater treatment is required for water resources pollution control in Africa. Environ Sci Technol 46: 7065-7066.

Palanisamy PG, Sasikala D, Mallikaraj NB, Natarajan GM. 2011. Electroplating industrial effluent chromium induced changes in carbohydrates metabolism in air breathing cat fish Mystus cavasius (ham). Asian J Exp Biol Sci 2: 521-524.

Paul D. 2017. Research on heavy metal pollution of river Ganga: a review. Ann Agrar Sci 15: 278-286.

Peat J, Barton B. 2005. Medical statistics: a guide to data analysis and critical appraisal. Oxford: Blackwell Publishing, 324 p.

Peterson JT, Bayley PB. 1993. Colonization rates of fishes in experimentally defaunated warmwater streams. Trans Am Fish Soc 122: 199-207.

R Core Team. 2017. R: a language and environment for statistical computing. Vienna (Austria): $\mathrm{R}$ Foundation for Statistical Computing, https://www.R-project.org/
Rahman AKA. 2005. Freshwater fishes of Bangladesh, 2nd ed. Dhaka, Bangladesh: Zoological Society of Bangladesh, $263 \mathrm{p}$.

Rajeshkumar S, Liu Y, Zhang X, Ravikumar B, Bai G, Li X. 2018. Studies on seasonal pollution of heavy metals in water, sediment, fish and oyster from the Meiliang Bay of Taihu Lake in China. Chemosphere 191: 626-638.

Ramachandra TV, Sudarshan PB, Mahesh MK, Vinay S. 2018. Spatial patterns of heavy metal accumulation in sediments and macrophytes of Bellandur wetland, Bangalore. J Environ Manag 206: 1204-1210.

Rezania S, Ponraj M, Talaiekhozani A, et al. 2015. Perspectives of phytoremediation using water hyacinth for removal of heavy metals, organic and inorganic pollutants in wastewater. J Environ Manag 163: 125-133.

Sabater S, Barcel D, Castro-Catal ND, et al. 2016. Shared effects of organic microcontaminants and environmental stressors on biofilms and invertebrates in impaired rivers. Environ Pollut 210: 303-314.

Sanchez W, Sremski W, Piccini B, et al. 2011. Adverse effects in wild fish living downstream from pharmaceutical manufacture discharges. Environ Int 37: 1342-1348

Schwarz CJ. 2015. Analysis of BACI experiments. In: Course Notes for Beginning and Intermediate Statistics. Available at http://www. stat.sfu.ca/ cschwarz/CourseNotes. Retrieved 2015- 08-20.

Sepulveda-Jauregui A, Hoyos-Santillan J, Gutierrez-Mendieta FJ, Torres-Alvarado R, Dendooven L, Thalasso F. 2013. The impact of anthropogenic pollution on limnological characteristics of a subtropical highland reservoir "Lago de Guadalupe", Mexico. Knowl Manag Aquat Ecosyst 410: 04.

Sheldon AL, Meffe GK. 1995. Short-term recolonization by fishes of experimentally defaunated pools of a coastal plain stream. Copeia 1995: 828-837.

Talwar PK, Jhingran AG. 1991. Inland Fishes of India and Adjacent Countries, Vol. 1 and 2. New Delhi-Calcutta (India): Oxford and IBH Publishing Co. Pvt. Ltd., 1158 p.

Uggetti E, Ferrer I, Arias C, Brix H, Garcia J. 2012. Carbon footprint of sludge treatment reed beds. Ecol Eng 44: 298-302.

Vaseem H, Banerjee TK. 2013. Contamination of the River Ganga and its toxic implication in the blood parameters of the major carp Labeo rohita (Ham). Environ Sci Pollut Res 20: 5673-5681.

Vorosmarty CJ, Mcintyre PB, Gessner MO, Dudgeon D, Prusevich A, Green $\mathrm{P}$, et al. 2010. Global threats to human water security and river biodiversity. Nature 467: 555-561.

Warren ML, Pardew MG. 1998. Road crossings as barriers to small stream fish movements. Trans Am Fish Soc 127: 637-644.

Yazıc1 Z, Sisman T. 2014. Genotoxic effects of water pollution on two fish species living in Karasu River, Erzurum, Turkey. Environ Monit Assess 186: 8007-8016.

Zuur AF, Ieno EN, Elphick CS. 2010. A protocol for data exploration to avoid common statistical problems. Methods Ecol Evol 1: 3-14.

Cite this article as: Galib SM, Mohsin ABM, Parvez MT, Lucas MC, Chaki N, Arnob SS, Hossain MI, Islam MN. 2018. Municipal wastewater can result in a dramatic decline in freshwater fishes: a lesson from a developing country. Knowl. Manag. Aquat. Ecosyst., $419,37$. 